\section{White Oak and Northern Red Oak Leaf Injury from Exposure to Chloroacetanilide Herbicides}

\author{
Jayesh B. Samtani ${ }^{1}$, John B. Masiunas ${ }^{2}$, and James E. Appleby \\ Department of Natural Resources and Environmental Sciences, University of \\ Illinois, 1201 W. Gregory Drive, Urbana, IL 61801
}

Additional index words. Quercus alba, Quercus rubra, acetochlor, s-metolachlor, dimethenamid-P, atrazine, leaf unfolding stage, herbicide drift

\begin{abstract}
Previous research by the authors found simulated acetochlor (with atrazine) and s-metolachlor drift to white oak at the leaf unfolding stage caused loss of interveinal tissues (leaf tatters). Reports of leaf tatters in the landscape and nursery settings are more common on white oak (Quercus alba L.) than on northern red oak (Quercus rubra L.). Our objectives were to determine if white and northern red oak differed in susceptibility to chloroacetanilide herbicides, if injury varied between chloroacetanilide herbicides, and if adding atrazine increased leaf injury. Two-year-old seedlings at the leaf unfolding stage were treated with acetochlor, s-metolachlor, and dimethenamid-P alone or combined with atrazine at $1 \%, 10 \%$, and $25 \%$ of the standard field use rate. Within 6 days, all chloroacetanilides at $10 \%$ and $25 \%$ field use rates, alone or combined with atrazine, caused leaf tatter injury in both species. Acetochlor, s-metolachlor, and dimethenamid-P caused a similar type of leaf injury. Atrazine did not cause loss of leaf tissues or increase injury from chloroacetanilides. At $1 \%$ field use rate, only acetochlor, acetochlor + atrazine, and dimethenamid-P caused leaf injury to northern red oaks. The white oaks were not injured by all of the chloroacetanilide treatments at $1 \%$ field use rate. The northern red oaks were slightly more susceptible to chloroacetanilides compared with the white oaks. A second study found acetochlor only injured northern red oak when applied at the leaf unfolding stage and only at $25 \%$ of field use rate. Acetochlor at $1 \%$ field use rate did not injure red oak. Research is needed to explain the greater frequency of leaf tatters on white oaks than on northern red oaks in the landscape and to develop strategies to avoid tree injury.
\end{abstract}

Beginning in the early 1980 s, there were reports of white oak (Quercus alba L.) leaves losing interveinal tissues throughout the Midwest [Green, 1985; Haugen et al., 2000; Leatherberry et al., 2004; Wisconsin Department of Agriculture, Trade and Consumer Protection (WDATCP), 2003]. The first flush of affected white oak leaves in the spring may lose most interveinal tissues, resulting in only the main veins and some residual interveinal tissues (leaf tatters). Leaf tatters can affect a substantial portion of a white oak tree's canopy reducing its overall health, making it

Received for publication 30 Oct. 2009. Accepted for publication 22 Feb. 2010.

This study was partly funded by the USDA Forest Service Evaluation Monitoring Program under Award Numbers AG FS 04-DG-11244225-247 and AG FS 06-DG-11244225-117.

We thank Mason State Nursery in Topeka, IL, for donating the white oak seedlings, and Dean E. Riechers for his suggestions to this study. For reviewing the manuscript before submission, we thank Gary Kling, Margaret Norton, and Dan Anderson.

${ }^{1}$ Former Graduate Research Assistant. Currently Post-Doctoral Research Associate, Department of Plant Sciences, University of California, Davis, 1636 E. Alisal Street, Salinas, CA 93905.

${ }^{2}$ To whom reprint requests should be addressed; e-mailmasiunas@illinois.edu. decreased from $8 \%$ in 1995 to $1 \%$ in 2005 . Lack of surveys on the leaf tatters, the growth-stage specificity of the injury on oaks, and the timing of chloroacetanilide applications hinders determining any correlation between leaf tatter injury and acres treated with chloroacetanilides.

In susceptible plants, chloroacetanilides inhibit $\beta$-ketoacyl-CoA synthase that adds two carbon units from malonyl-coenzyme A (CoA) to a $\mathrm{C} 18$ fatty acid (Lassner et al., 1996; Millar and Kunst, 1997). Inhibition of $\beta$-ketoacyl-CoA synthase depletes very-long chain fatty acids (VLCFA) in susceptible plants. The major site of VLCFA synthesis is in the epidermal cells where they are used for production of waxes that cover the aerial surfaces of plants (Millar and Kunst, 1997; Post-Beittenmiller, 1996). In oaks, wax deposition occurs during leaf expansion (Neinhuis and Barthlott, 1998; Osborn and Taylor, 1990), which is consistent with our previous finding that white oak at the leaf unfolding stage is injured by chloroacetanilides

Within Illinois in $2006,87 \%$ of the corn acreage was treated with atrazine and it is common to use premixes of atrazine with chloroacetanilides for a broader range of weed control (Taylor-Lovell and Wax, 2001; U.S. Department of Agriculture, 2006). In tolerant plants, both atrazine and chloroacetanilide herbicides are rapidly detoxified by conjugation with glutathione (Marrs, 1996; Shukla and Devine, 2006). In susceptible plants, atrazine may interact with chloroacetanilide herbicides to increase leaf tatter injury. Atrazine also inhibits electron flow through Photosystem II, reducing subsequent carbon assimilation into sugars (Trebst, 2006). The reduction in primary carbon assimilation could reduce fatty acid synthesis, compounding chloroacetanilide inhibition of VLCFA synthesis. Atrazine has a synergistic interaction with some herbicides such as mesotrione and alachlor, increasing weed injury and control (Akobundu et al., 1975; Bollman et al., 2006).

In the midwestern United States, the relatively flat topography and intermingling of agricultural fields, natural areas, and residential development contribute to herbicide drift injury. Off-target herbicide movement is between $1 \%$ and $10 \%$ of field use rates (Al-Khatib and Peterson, 1999; Al-Khatib et al., 2003). Herbicide drift modifies plant morphology and development, potentially altering species composition and diversity (Boutin, 1999; Freemark and Boutin,1995). White oak and northern red oak are native to eastern North America from Nova Scotia to Minnesota, Kansas, and Georgia. Northern red oak is a fast-growing tree, withstands air pollution, and is considered one of the best oaks for city plantings (Dirr, 1990). Although the range of the two species overlap, reports of leaf tatter injury are more common on white than northern red oak. We hypothesized that red oaks are less susceptible to chloroacetanilides than white oak. We also hypothesized that the degree of leaf tatter injury varies among chloroacetanilides. The 
objectives were to determine if: 1) white and red oak differ in susceptibility to chloroacetanilide herbicides; 2) the amount of injury varies among acetochlor, s-metolachlor, and dimethenamid-P; and 3) atrazine applied with chloroacetanilides increases leaf tatters.

\section{Materials and Methods}

Interaction study. Two-year-old white and red oak seedlings (Mason State Nursery, Topeka, IL) were planted in 8.52-L plastic nursery containers and managed as previously described (Samtani et al., 2008). Seedlings were placed in an outdoor site $\approx 3 \mathrm{~km}$ from the nearest crop fields. This site was chosen to avoid oak injury from drift of herbicides applied to agricultural fields.

The oaks were spaced at $45 \times 45 \mathrm{~cm}$, center to center, in a randomized complete block design with five single-seedling replications, and the experiment was repeated once. The experiment was a four-way factorial with year, species (northern red or white oak), herbicide, and herbicide concentration $(1 \%, 10 \%$, and $25 \%$ standard field rate) as independent variables. Acetochlor was applied at $20(1 \%), 200(10 \%)$, and $500(25 \%)$ $\mathrm{g} \cdot \mathrm{ha}^{-1}$; s-metolachlor was applied at 21, 210, and $550 \mathrm{~g} \cdot \mathrm{ha}^{-1}$; and dimethenamid-P was applied at 8, 80, and $200 \mathrm{~g} \cdot \mathrm{ha}^{-1}$. Atrazine was applied at 23,230 , and $575 \mathrm{~g} \cdot \mathrm{ha}^{-1}$ alone or combined with chloroacetanilides. The control seedlings were sprayed with water. Seedlings were treated at the leaf unfolding stage on 8 June 2005 for both species and on 5 and 7 June 2006 for red and white oaks, respectively. In 2006, rate of leaf development differed between the two species. A layer of vermiculite was added to the soil surface before spraying and removed immediately afterward to prevent any herbicide absorption by the media. Herbicides were applied in a spray chamber at the Plant Care Facility of the University of Illinois using a compressed air sprayer equipped with a single 80015 EVS nozzle (Spraying Systems, Wheaton, IL) delivering $187 \mathrm{~L} \cdot \mathrm{ha}^{-1}$ at 207 $\mathrm{kPa}$. After the spray application dried, oak seedlings were moved back to the outdoor site.

Seedlings were photographed to document injury symptoms and plant recovery at 10, 20, and $82 \mathrm{~d}$ after treatment (DAT). The proportion of shoot tissues affected by herbicide injury was visually rated $(1=$ no injury to $10=$ all plant tissues injured). A second rating, specific for early season loss of interveinal tissues $(1=$ no tatters to $5=$ all opening leaves having tatters), was also conducted. The ratings were conducted approximately weekly. The repeated ratings allowed us to determine the rate of injury development, the extent of injury, and the rate of recovery.

Influence of growth stage on red oak injury. Our objective was to determine the effect of growth stage on susceptibility of red oak to chloroacetanilides. Acetochlor was used as a representative chloroacetanilide herbicide because it is widely used; consistently injured oaks in previous studies and all chloroacetanilides tested caused similar injury. Northern red oak seedlings in 2006 were donated by Mason State Nursery (Topeka, IL) and, in 2007, were purchased from Forrest Keeling Nursery (Elsberry, MO). Two-yearold seedlings were planted on 9 June 2006 and 25 Apr. 2007 in 8.52-L nursery containers using the same media and practices as previously described (Samtani et al., 2008). The experiment was a completely randomized design with five single-seedling replications and was repeated once. Year, concentration, and growth stage were independent variables. Northern red oaks were treated with acetochlor at $0 \%$ (untreated control), 1\% (20 $\left.\mathrm{g} \cdot \mathrm{ha}^{-1}\right)$, and $25 \%\left(500 \mathrm{~g} \cdot \mathrm{ha}^{-1}\right)$ of the standard field use rate. Acetochlor was applied as described at the swollen bud stage on 15 June 2006 and 4 May 2007; the leaf unfolding stage on 19 June 2006 and 10 May 2007; and the expanded leaf stage on 23 June 2006 and 31 May 2007. Spray application was allowed to dry and the northern red oaks were moved to the site used in previous studies and spaced as previously described. Weekly visual and leaf tatters injury were determined as previously described. All rating dates are DAT at the leaf unfolding stage.

Data analysis. Visual and tatter ratings at $15,45,85$ (interaction study), and 90 (growth stage study) DAT were analyzed using the proc mixed procedure in SAS (Release 8.02; SAS Institute Inc., Cary, NC). These dates were chosen to represent early, mid-, and late portions of the growing season. The data were tested for normality of residuals, and in only one instance, the 45 DAT visual ratings for the northern red oak growth stage study, the $\log _{10}$ (visual +0.5 ) transformation was used. Original means with the letters of the transformed data are presented in Figure 2. The Least Significance Difference test $(P=0.05)$ was used for mean separation. Letters for mean separation were assigned using a macro "PDMIX 800 " (Saxton, 1998). In the interaction study, plant responses to the chloroacetanilide herbicides and atrazine were characterized as additive, synergistic, or antagonistic using the procedure of Colby (1967). Differences between expected and observed responses were tested using Student's $t$ test $(P=0.05)$ and significant differences indicated synergism or antagonism.

\section{Results and Discussion}

Interaction study. Within 5 to 6 DAT, white and red oak seedlings treated with chloroacetanilide herbicides alone or with atrazine had necrosis (browning) of interveinal leaf tissues. The necrotic leaf tissues later dropped off, resulting in an appearance common for leaf tatters (Fig. 1). These symptoms were consistent with photographs of leaf tatter injury (Haugen et al., 2000; WDATCP, 2003) and results from our previous study (Samtani et al., 2008). Unlike field reports of leaf tatters limited only to white oaks, northern red oaks in our study were injured after treatment with chloroacetanilide herbicides (Table 1).
Atrazine injury symptoms ranged from minor chlorosis or necrotic spots to leaves completely necrotic and wilting. Oak leaf necrosis from atrazine developed more slowly than leaf tatters from chloroacetanilides ( 15 to 20 DAT versus 5 to 6 DAT, respectively) and the most severe injury was followed by abscission of the oak leaves. Atrazine injury was inconsistent with some plants in the 1\% (2005) and 25\% (2006) field use rate treatments having severe injury and other plants not injured (Table 2). Unlike our results, Wong and Romanowski (1968) found a linear response of cucumber to atrazine concentration ranging from slight to severe injury at less than 25 to $224 \mathrm{~g} \cdot \mathrm{ha}^{-1}$ atrazine, respectively. The slow development of symptoms and inconsistent atrazine injury to oaks was likely caused by use of tree seedlings and small amounts of absorptive leaf tissues at application.

At 15 DAT, species, chloroacetanilide herbicide and concentration interacted to determine oak visual injury (Table 1). Proportion of shoot tissues affected and leaf tatter ratings were highly correlated $(r=$ 0.98 and 0.97 for northern red and white oak, respectively) because most visual injury (except atrazine alone) was loss of interveinal tissues. Thus, only the visual injury data are discussed. A comparison of mean separations using Colby's formula (Colby, 1967) found atrazine combined with a chloroacetanilide did not decrease or increase visual or leaf tatter injury compared with chloroacetanilides applied alone. Romanowski (1980) found alachlor combined with atrazine caused a synergistic reduction in tomato (Lycopersicon esculentum Mill.) yield. In our study, atrazine application rates were lower than Romanowski (1980).

Northern red and white oaks were both injured by chloroacetanilides but differed in their response to specific herbicide concentrations. White oak seedlings were not injured (proportion of tissues or tatter ratings) by any chloroacetanilide at the $1 \%$ concentration, whereas red oak was injured from acetolchlor, acetochlor + atrazine, and dimethenamid-P at $1 \%$ field use rate (Table 1). At $10 \%$ and $25 \%$ field rates, all chloroacetanilides caused visual and leaf tatter injury to red oak. Northern red oak developed earlier than white oak; hence, it was treated on 5 June 2006, whereas white oak was treated on 7 June. Although the temperatures were cooler on 5 June (high $28^{\circ} \mathrm{C}$ and low $13^{\circ} \mathrm{C}$ ) than on 7 June (high $31{ }^{\circ} \mathrm{C}$ and low $18{ }^{\circ} \mathrm{C}$ ) and high temperatures dropped to $19{ }^{\circ} \mathrm{C}$ on 10 June (Illinois State Water Survey, 2009), the differences were unlikely to explain the greater injury to red oak. There were differences in white oak injury between specific chloroacetanilides applied at $10 \%$ but not the $25 \%$ field use rate (Table 1). S-metolachlor at $10 \%$ field use rate without atrazine caused more injury than acetochlor or dimethenamid-P. In our previous study (Samtani et al., 2008), s-metolachlor and acetochlor + atrazine caused similar amounts of injury to white oak seedlings. Also, chloroacetanilide 

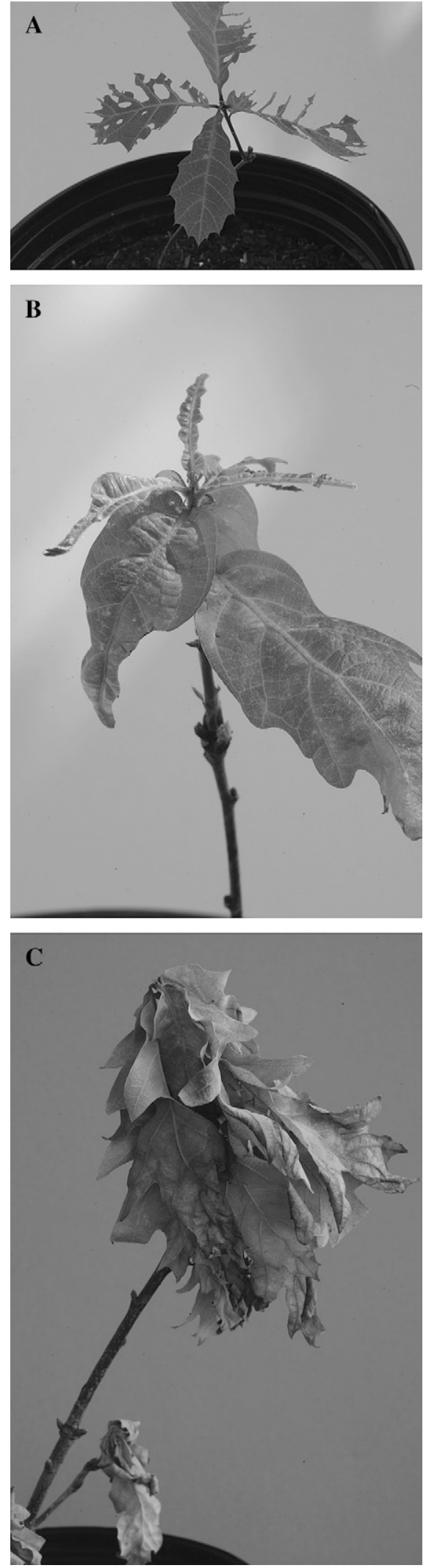

Fig. 1. (A) Leaf tatters on red oak treated with acetochlor + atrazine at $1 \%$ field use rate $10 \mathrm{~d}$ after treatment (DAT); (B) white oak treated with s-metolachlor at $10 \%$ field use rate 10 DAT resulting in leaf tatters; and $(\mathbf{C})$ wilting and browning of leaves of white oak treated with atrazine at $25 \%$ field use rate concentration 20 DAT.

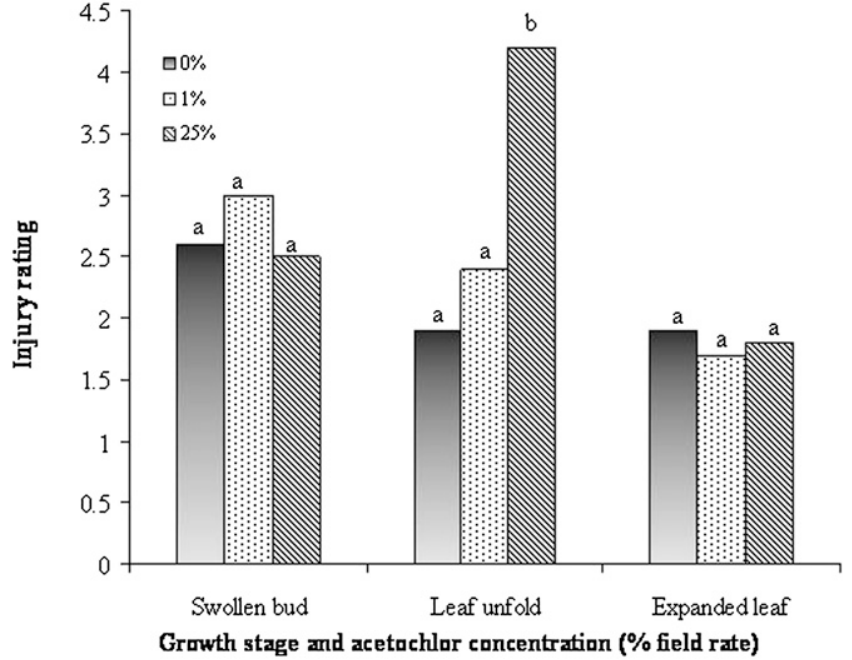

Fig. 2. The interaction of acetochlor concentration and northern red oak growth stage influenced visual leaf injury $(1=$ no injury to $10=$ plant dead $)$ at $45 \mathrm{~d}$ after treatment at the leaf unfolding stage. Acetochlor concentrations were $20(1 \%)$ and $500(25 \%) \mathrm{g} \cdot \mathrm{ha}^{-1}$. Bars with the same letter are not significantly different using least significant difference in proc mixed at $P \leq 0.05$.

Table 1. Interaction of herbicide and concentration determined injury ${ }^{\mathrm{z}}$ on red and white oaks $15 \mathrm{~d}$ after treatment. ${ }^{y}$

\begin{tabular}{|c|c|c|c|c|c|c|}
\hline \multirow[b]{3}{*}{ Herbicide treatment ${ }^{\mathrm{x}}$} & \multicolumn{3}{|c|}{ Red oaks } & \multicolumn{3}{|c|}{ White oaks } \\
\hline & \multicolumn{3}{|c|}{ Herbicide ( $\%$ field rate) } & \multicolumn{3}{|c|}{ Herbicide ( $\%$ field rate) } \\
\hline & 1 & 10 & 25 & 1 & 10 & 25 \\
\hline Control & -------- & $-1.2 \mathrm{k}^{\mathrm{w}, \mathrm{v}}$ & -------- & ------- & $--1.1 \mathrm{k}-$ & --------- \\
\hline Atrazine & $2.9 \mathrm{f}-\mathrm{k}$ & $1.7 \mathrm{jk}$ & $2.0 \mathrm{i}-\mathrm{k}$ & $2.3 \mathrm{~h}-\mathrm{k}$ & $1.1 \mathrm{k}$ & $2.2 \mathrm{~h}-\mathrm{k}$ \\
\hline Acetochlor & $3.7 \mathrm{c}-\mathrm{i}$ & $5.3 \mathrm{a}-\mathrm{c}$ & $4.8 \mathrm{a}-\mathrm{e}$ & $1.7 \mathrm{jk}$ & $2.0 \mathrm{i}-\mathrm{k}$ & $4.3 \mathrm{a}-\mathrm{g}$ \\
\hline Acetochlor + atrazine & $3.2 \mathrm{e}-\mathrm{j}$ & $3.4 \mathrm{~d}-\mathrm{j}$ & $4.0 \mathrm{a}-\mathrm{h}$ & $1.8 \mathrm{jk}$ & $2.8 \mathrm{f}-\mathrm{k}$ & $3.9 \mathrm{~b}-\mathrm{h}$ \\
\hline Dimethenamid-P & $3.2 \mathrm{e}-\mathrm{j}$ & $4.3 \mathrm{a}-\mathrm{g}$ & $5.8 \mathrm{a}$ & $2.3 \mathrm{~h}-\mathrm{k}$ & $3.5 \mathrm{c}-\mathrm{j}$ & $3.1 \mathrm{e}-\mathrm{j}$ \\
\hline Dimethenamid-P + atrazine & $2.3 \mathrm{~h}-\mathrm{k}$ & $4.6 \mathrm{a}-\mathrm{f}$ & $4.4 \mathrm{a}-\mathrm{g}$ & $2.0 \mathrm{i}-\mathrm{k}$ & $2.2 \mathrm{~h}-\mathrm{k}$ & $3.5 \mathrm{c}-\mathrm{j}$ \\
\hline S-metolachlor & $2.9 \mathrm{f}-\mathrm{k}$ & $3.2 \mathrm{e}-\mathrm{j}$ & $5.2 \mathrm{a}-\mathrm{d}$ & $2.0 \mathrm{i}-\mathrm{k}$ & $5.7 \mathrm{ab}$ & $4.0 \mathrm{a}-\mathrm{h}$ \\
\hline S-metolachlor + atrazine & $2.6 \mathrm{~g}-\mathrm{k}$ & $3.9 \mathrm{~b}-\mathrm{h}$ & $4.5 \mathrm{a}-\mathrm{f}$ & $2.0 \mathrm{i}-\mathrm{k}$ & $3.7 \mathrm{c}-\mathrm{i}$ & $4.9 \mathrm{a}-\mathrm{e}$ \\
\hline
\end{tabular}

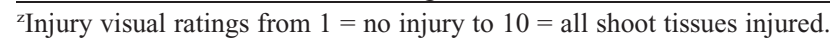

${ }^{\mathrm{y}}$ Results are averaged over years.

${ }^{x}$ Percentage of standard field use rate. Standard field use rates are atrazine at $2300 \mathrm{~g} \cdot \mathrm{ha}{ }^{-1}$, acetochlor at $2000 \mathrm{~g} \cdot \mathrm{ha}^{-1}$, dimethenamid-P at $800 \mathrm{~g} \cdot \mathrm{ha}^{-1}$, and s-metolachlor at $2100 \mathrm{~g} \cdot \mathrm{ha}^{-1}$.

weans with the same letter across columns and rows are not significantly different using least significant difference in proc mixed at $P \leq 0.05$.

${ }^{v}$ Visual ratings greater than control ratings are the result of leaf tatter injury (chloroacetanilide) or tatter injury along with wilting and slight necrosis of leaves (chloroacetanilides + atrazine).

visual ratings of injury to white oak ranged from 1.8 to 5.7 in this study compared with 3 to 7.7 in the previous study. Differences in temperature at the time of treatment and in the duration of the leaf unfolding growth stage could explain dissimilarities in injury between the two studies. The variation between studies illustrates the difficulty in predicting the leaf unfolding stage and may indicate the difficulty farmers would have in timing chloroacetanilide applications to avoid injury to neighboring oaks.

At 45 and 85 DAT, northern red oak and white oak had similar amounts of recovery from chloroacetanilide injury; thus, results in Table 2 were averaged over species. The leaf tatter injury and similar amounts of recovery suggest that northern red oak has a susceptible $\beta$-ketoacyl-CoA synthase and does not rapidly metabolize chloroacetanilide during the leaf unfolding stage. The more frequent reports of leaf tatter injury to white oak than red oak may be the result of differences in species distribution and leaf development in the landscape in relation to chloroacetanilide applications. Northern red oaks may not be common near fields treated with chloroacetanilides or the trees may not be in the susceptible leaf unfolding stage when the herbicides are applied.

Year, herbicide, and concentration interacted to determine injury at 45 and 85 DAT (Table 2). In 2006, new uninjured leaves were produced before the 45 DAT rating, unlike 2005 when new growth was seen $\approx 55$ DAT. New uninjured leaves reduced the portion of the plant tissues injured and was consistent with field reports (Haugen et al., 2000; Leatherberry et al., 2004; WDATCP, 2003) and our previous study (Samtani et al., 2008). The difference in growth rate between years may have been related to more frequent cold fronts and greater fluctuations in high temperatures in 2005 than 2006 (Illinois State Water Survey, 2009). In 2005, chloroacetanilides differed in their potential to injure oaks. For example, at $45 \mathrm{DAT}$, the $1 \%$ rate of dimethenamid-P injured oaks more than 
Table 2. Interaction of year, herbicide, and concentration affected red and white oak injury ${ }^{\mathrm{z}}$ at 45 and 85 $\mathrm{d}$ after treatment (DAT). ${ }^{\mathrm{y}}$

\begin{tabular}{|c|c|c|c|c|c|c|}
\hline \multirow[b]{4}{*}{ Herbicide treatment ${ }^{\mathrm{x}}$} & \multicolumn{3}{|c|}{2005} & \multicolumn{3}{|c|}{2006} \\
\hline & \multicolumn{3}{|c|}{ Herbicide ( $\%$ field rate) } & \multicolumn{3}{|c|}{ Herbicide ( $\%$ field rate) } \\
\hline & 1 & 10 & 25 & 1 & 10 & 25 \\
\hline & \multicolumn{6}{|c|}{$45 \mathrm{DAT}$} \\
\hline Control & \multicolumn{3}{|c|}{---------------1.9 jk ${ }^{\mathrm{w}}$-------------- } & \multicolumn{3}{|c|}{ 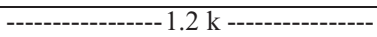 } \\
\hline Atrazine & $4.4 \mathrm{c}-\mathrm{h}$ & $2.7 \mathrm{~h}-\mathrm{k}$ & $2.6 \mathrm{~h}-\mathrm{k}$ & $2.0 \mathrm{jk}$ & $1.6 \mathrm{jk}$ & $4.0 \mathrm{c}-\mathrm{i}$ \\
\hline Acetochlor & $2.7 \mathrm{~h}-\mathrm{k}$ & $3.3 \mathrm{e}-\mathrm{j}$ & $6.8 \mathrm{a}$ & $2.3 \mathrm{i}-\mathrm{k}$ & $2.6 \mathrm{~h}-\mathrm{k}$ & $2.3 \mathrm{i}-\mathrm{k}$ \\
\hline Acetochlor + atrazine & $3.5 \mathrm{~d}-\mathrm{j}$ & $3.5 \mathrm{~d}-\mathrm{j}$ & $5.1 \mathrm{a}-\mathrm{f}$ & $2.2 \mathrm{i}-\mathrm{k}$ & $3.2 \mathrm{f}-\mathrm{j}$ & $1.6 \mathrm{jk}$ \\
\hline Dimethenamid-P & $5.8 \mathrm{a}-\mathrm{c}$ & $4.8 \mathrm{~b}-\mathrm{g}$ & $6.6 \mathrm{ab}$ & $1.9 \mathrm{jk}$ & $2.7 \mathrm{~h}-\mathrm{k}$ & $2.2 \mathrm{i}-\mathrm{k}$ \\
\hline Dimethenamid-P + atrazine & $2.6 \mathrm{~h}-\mathrm{k}$ & $5.2 \mathrm{a}-\mathrm{e}$ & $5.4 \mathrm{a}-\mathrm{d}$ & $1.9 \mathrm{jk}$ & $2.3 \mathrm{i}-\mathrm{k}$ & $3.0 \mathrm{~g}-\mathrm{k}$ \\
\hline S-metolachlor & $2.5 \mathrm{~h}-\mathrm{k}$ & $5.3 \mathrm{a}-\mathrm{d}$ & $7.0 \mathrm{a}$ & $1.9 \mathrm{jk}$ & $4.8 \mathrm{~b}-\mathrm{g}$ & $2.1 \mathrm{i}-\mathrm{k}$ \\
\hline \multirow[t]{2}{*}{ S-metolachlor + atrazine } & $3.0 \mathrm{~g}-\mathrm{k}$ & $5.6 \mathrm{a}-\mathrm{c}$ & $5.3 \mathrm{a}-\mathrm{d}$ & $1.8 \mathrm{jk}$ & $2.0 \mathrm{jk}$ & $3.5 \mathrm{~d}-\mathrm{j}$ \\
\hline & \multicolumn{6}{|c|}{$85 \mathrm{DAT}$} \\
\hline Control & - & $-2.8 \mathrm{~h}-1$ & --------- & -------. & $--1.61--$ & --------- \\
\hline Atrazine & $5.4 \mathrm{a}-\mathrm{c}$ & $3.1 \mathrm{f}-1$ & $3.3 \mathrm{~d}-1$ & $3.3 \mathrm{~d}-1$ & $2.1 \mathrm{j}-1$ & $4.5 \mathrm{a}-\mathrm{h}$ \\
\hline Acetochlor & $3.7 \mathrm{c}-\mathrm{k}$ & $3.1 \mathrm{f}-1$ & $4.8 \mathrm{a}-\mathrm{f}$ & $2.8 \mathrm{~h}-1$ & $2.7 \mathrm{i}-1$ & $2.8 \mathrm{~h}-1$ \\
\hline Acetochlor + atrazine & $3.8 \mathrm{c}-\mathrm{j}$ & $3.2 \mathrm{e}-1$ & $5.0 \mathrm{a}-\mathrm{d}$ & $2.0 \mathrm{kl}$ & $4.3 \mathrm{~b}-\mathrm{i}$ & $2.4 \mathrm{j}-1$ \\
\hline Dimethenamid-P & $4.6 \mathrm{a}-\mathrm{g}$ & $4.2 \mathrm{~b}-\mathrm{i}$ & $4.7 \mathrm{a}-\mathrm{f}$ & $2.2 \mathrm{j}-1$ & $3.1 \mathrm{f}-1$ & $2.9 \mathrm{~g}-1$ \\
\hline Dimethenamid-P + atrazine & $2.9 \mathrm{~g}-1$ & $6.2 \mathrm{a}$ & $4.9 \mathrm{a}-\mathrm{e}$ & $2.4 \mathrm{j}-1$ & $2.7 \mathrm{i}-1$ & $3.2 \mathrm{e}-1$ \\
\hline S-metolachlor & $2.8 \mathrm{~h}-1$ & $3.3 \mathrm{~d}-1$ & $5.6 \mathrm{ab}$ & $2.2 \mathrm{j}-1$ & $4.9 \mathrm{a}-\mathrm{e}$ & $2.2 \mathrm{j}-1$ \\
\hline S-metolachlor + atrazine & $2.7 \mathrm{i}-1$ & $4.4 \mathrm{~b}-\mathrm{i}$ & $4.2 \mathrm{~b}-\mathrm{i}$ & $2.0 \mathrm{kl}$ & $2.8 \mathrm{~h}-1$ & $4.7 \mathrm{a}-\mathrm{f}$ \\
\hline
\end{tabular}

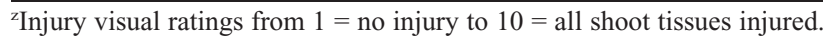

${ }^{\mathrm{y}}$ Results are averaged over species.

xPercentage of standard field use rate. Standard field use rates are atrazine at $2300 \mathrm{~g} \cdot \mathrm{ha}^{-1}$, acetochlor at $2000 \mathrm{~g} \cdot \mathrm{ha}^{-1}$, dimethenamid-P at $800 \mathrm{~g} \cdot \mathrm{ha}^{-1}$, and s-metolachlor at $2100 \mathrm{~g} \cdot \mathrm{ha}^{-1}$.

${ }^{w}$ Means with the same letter across columns and rows for each DAT are not significantly different using least significant difference in proc mixed at $P \leq 0.05$.

acetochlor or s-metolachlor. Bollman et al. (2008) reported that dimethenamid-P injured sugarbeet more than s-metolachlor as a result of reduced and slower translocation.

Overall, the $10 \%$ and $25 \%$ field use rate of chloroacetanilides caused greater injury than $1 \%$ concentration. Other studies found susceptible plants have more injury at higher doses of herbicides (Burke et al., 2005; Ellis et al., 2003). The concentration dependency of leaf tatters injury suggests that trees further from chloroacetanilide applications would have less injury.

Influence of growth stage on red oak injury. Leaf tatter injury to red oak occurred only at the leaf unfolding stage (Fig. 2), similar to our results in a previous study with white oak (Samtani et al., 2008). Acetochlor only injured red oak at $25 \%$ but not at $1 \%$ of the field use rate. Red oak seedlings treated with acetochlor at the swollen bud and expanded leaf stages were not injured compared with control plants. New leaves produced later in the growing season were not injured. This study confirmed that northern red oak susceptibility is growth stage-dependent, similar to our previous findings with white oak (Samtani et al., 2008).

Prior research on herbicide drift shows that plant response is usually less severe as herbicide dose is reduced. Other factors such as phenological stage of the plant at the time of exposure, environment, year, or the plant cultivar being tested can affect both the severity and type of injury symptoms. (Olszyk et al., 2004). There are several ways to minimize herbicide drift to oaks. In the field, applying chloroacetanilide herbicides either before or after the susceptible leaf unfolding stage of oaks could potentially minimize injury, but our research found it difficult to predict the leaf unfolding stage. Buffer zones
(6 to $20 \mathrm{~m}$ ) can reduce chloroacetanilide concentrations below $1 \%$ field use rates and protect surrounding nature reserves and other sensitive habitats from drift injury (Marrs et al., 1993). Landowners concerned about the health and aesthetics of their oaks should communicate with neighboring farmers and make pesticide applicators aware of chloroacetanilide susceptibility of red and white oaks. If oaks are near agricultural fields, we recommend farmers use large droplet sizes, lower boom heights, and add drift inhibitors. Chloroacetanilide applications should be made in the absence of cross winds, when wind speeds are less than $15 \mathrm{k} \cdot \mathrm{h}^{-1}$, and be directed away from the trees. The prevalent use of chloroacetanilide herbicides in midwestern corn fields, the lack of prior research, and findings from this study highlight the need of additional research involving drift effects of chloroacetanilides on woody plant materials. Research is also needed to explain the difference in leaf tatters reported in the landscape between the white oak and northern red oak species.

\section{Literature Cited}

Akobundu, I.O., R.D. Sweet, and W.B. Duke 1975. A method of evaluating herbicide combinations and determining herbicide synergism. Weed Sci. 23:20-25.

Al-Khatib, K., M.M. Claassen, P.W. Stahlman, P.W. Geier, D.L. Regehr, S.R. Duncan, and W.F. Heer. 2003. Grain sorghum response to simulated drift from glufosinate, glyphosate, imazethapyr, and sethoxydim. Weed Technol. 17:261-265.

Al-Khatib, K. and D. Peterson. 1999. Soybean (Glycine max) response to simulated drift from selected sulfonylurea herbicides, dicamba, glyphosate and glufosinate. Weed Technol. 13:264-270.
Bollman, S.L., J.J. Kells, and D. Penner. 2006. Weed response to mesotrione and atrazine applied alone and in combination preemergence. Weed Technol. 20:903-907.

Bollman, S.L., C.L. Sprague, and D. Penner. 2008. Physiological basis for tolerance of sugarbeet varieties to s-metolachlor and dimethenamid-P. Weed Sci. 56:18-25.

Boutin, C. 1999. Herbicides, defoliants, p. 316 319. In: Alexander, D.E. and R.W. Fairbridge (eds.). Encylcopedia of environmental science. Encyclopedia of earth sciences series. Kluwer Academic Publishers, Boston, MA

Burke, I.C., W.E. Thomas, W.A. Pline-Srnić, L.R. Fisher, W.D. Smith, and J.W. Wilcut. 2005. Yield and physiological response of flue-cured tobacco to simulated glyphosate drift. Weed Technol. 19:255-260.

Colby, S.R. 1967. Calculating synergistic and antagonistic responses of herbicide combinations. Weeds 15:20-22.

Dirr, M.A. 1990. Manual of woody landscape plants: Their identification, ornamental characteristics, culture, propagation and uses. Stipes, Champaign, IL.

Ellis, J.M., J.L. Griffin, S.D. Linscombe, and E.P. Webster. 2003. Rice (Oryza sativa) and corn (Zea mays) response to simulated drift of glyphosate and glufosinate. Weed Technol. 17:452-460.

Freemark, K. and C. Boutin. 1995. Impacts of agricultural herbicide use on terrestrial wildlife in temperate landscapes: A review with special reference to North America. Agr. Ecosystems and Environ. 52:67-91.

Green, R.J. 1985. 'Leaf tatters'-A malady of unknown cause of oaks. Amer. Phytopathol. Soc. North Central Div. Mtg. 75:963 (abstract).

Haugen, L., P. Marshall, J.C. Carlson, M. Vitosh, and E. Hayes. 2000. Oak tatters. U.S. Department of Agriculture Pest Alert. 23 Feb. 2010. <http:// www.na.fs.fed.us/spfo/pubs/pest_al/oaktatters/ oaktatters.htm>.

Illinois State Water Survey. 2009. Local climatological data, Champaign-Urbana, IL-118740, June 2007. 23 Feb. 2010. <http://www.isws. illinois.edu/atmos/statecli/cuweather/index. htm>.

Lassner, M.W., K. Lardizabal, and J.G. Metz. 1996. A jojoba $\beta$-ketoacyl-CoA synthase cDNA complements the canola fatty acid elongation mutation in transgenic plants. Plant Cell 8:281-292

Leatherberry, E.C., G.J. Brand, and D.C. Little. 2004. Illinois Forest Resources in 2002. USDA Forest Service. North Central Research Station. Resource Bul. NC-236.

Marrs, K.A. 1996. The functions and regulation of glutathione s-transferases in plants. Annu. Rev. Plant Physiol. Plant Mol. Biol. 47:127-158.

Marrs, R.H., A.J. Frost, R.A. Plant, and P. Lunnis. 1993. Determination of buffer zones to protect seedlings of non-target plants from the effects of glyphosate spray drift. Agr. Ecosystems and Environ. 45:283-293.

Millar, A.A. and L. Kunst. 1997. Very-long-chain fatty acid biosynthesis is controlled through the expression and specificity of the condensing enzyme. Plant J. 12:121-131.

Neinhuis, C. and W. Barthlott. 1998. Seasonal changes of leaf surface contamination in beech, oak, and ginkgo in relation to leaf micromorphology and wettability. New Phytol. 138:91-98.

Olszyk, D.M., C.A. Burdick, T.G. Pfleeger, E.H. Lee, and L.S. Watrud. 2004. Assessing the risks to non-target terrestrial plants from herbicides. J. Agr. Meteorol. 60:221-242. 
Osborn, J.M. and T.N. Taylor. 1990. Morphological and ultrastructural studies of plant cuticular membranes. I. Sun and shade leaves of Quercus velutina (Fagaceae). Bot. Gaz. 151:465-476.

Post-Beittenmiller, D. 1996. Biochemistry and molecular biology of wax production in plants. Annu. Rev. Plant Physiol. Plant Mol. Biol. 47:405-430

Romanowski, R.R. 1980. Simulated drift studies with herbicides on field-grown tomato. HortScience 15:793-794.

Samtani, J.B., J.B. Masiunas, and J.E. Appleby. 2008. Injury on white oak seedlings from herbicide exposure simulating drift. HortScience 43:2076-2080.

Saxton, A.M. 1998. A macro for converting mean separation output to letter groupings in Proc
Mixed. In: Proc. 23rd SAS Users Group Intl., SAS Institute, Cary, NC.

Shukla, A. and M.D. Devine. 2006. Basis of crop selectivity and weed resistance to triazine herbicides, p. 111-118. In: LeBaron, H.M., J.E. McFarland, and O. Burnside (eds.). Triazine herbicides: 50 years revolutionizing agriculture. Elsevier Science, Burlington, MA.

Taylor-Lovell, S. and L.M. Wax. 2001. Weed control in field corn (Zea mays) with RPA 201772 combinations with atrazine and smetolachlor. Weed Technol. 15:249-256.

Trebst, A. 2006. The mode of action of triazine herbicides, p. 101-110. In: LeBaron, H.M., J.E. McFarland, and O. Burnside (eds.). Triazine herbicides: 50 years revolutionizing agriculture. Elsevier Science, Burlington, MA.
U.S. Department of Agriculture. 1996. Agricultural chemical usage 1995 field crops summary. 23 Jan. 2010. <http://jan-tng.mannlib.cornell. edu/reports/nassr/other/pcu-bb/agch0396. txt>.

U.S. Department of Agriculture. 2006. Agricultural chemical usage 2005 field crops summary. 23 Jan. 2010. <http://jan-tng.mannlib.cornell.edu/ reports/nassr/other/pcu-bb/agcs0506.pdf $>$.

Wisconsin Department of Agriculture, Trade and Consumer Protection. 2003. Wisconsin Pest Bulletin 48:70-79. 23 Feb. 2010. <http:// pestbulletin.wi.gov/pdf/2003/June6web.pdf $>$.

Wong, M.K. and R.R. Romanowski, Jr. 1968. A relationship between foliar symptoms and tissue content of cucumbers sprayed with atrazine. Weed Sci. 16:441-443. 